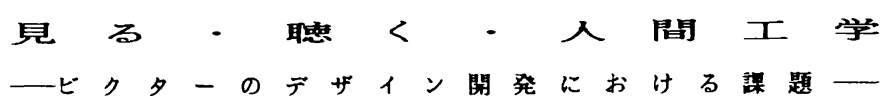

\author{
日本ビクター株式会社 \\ P \& S ンター
}

長島蚛之

中沢金四郎
1 はじめに

今日、私達の生活の周辺至るところに音架 があ。

当社は昭和 2 年に創莱して以来、音慗を愛 する人々と共に昭和の歴史を辿ってきた。

“原音探究”のキーワートのもとに、音を 忠実に再現するオリジナルな技街の創造閉発 は、創業以来先人達かこだわり続けてきた企 業の装勢てあった。

技街䩢新生质を変䩚すトリガーとなっ て推移した時代を経て、音のビクタ一は今、 音と映像のビクターに、と領域を搪げている。

音踣分野の H I - F I 化、映偻分野の八イ クォリティ化は人類にとって誰も体唫した事 のない想像世界の体的哭可能な状況になっ てきている。

\section{2 映像㻴境の推移展開}

映像情報普及の推移を振りかえってみると 映使家庭に初めて届いたのは昭和 30 年に 白黒テレビジョンが登場した時からてある。

昭和 40 年にはカラーテレビジョンが普及 し始めたかこの時点ては送り侧か一方的に家 庭の茶の間に映像を流していた。

昭和 53 年にはホーム V T R か出現して、 私達は放送番組を記録し、好きな時間を選ん て見られる梾になった。
これを機会にしてビデオレンタル産業が急 速に普及し、多くのビデオンフトのなかから 選ふことも可能になった。

昭和 60 年、ビデオティスクの登場は、婁 かな映像ソフトの中から選択の永拡が一 方、ビテオデスクのランダムアクセス機能 を利用しな映像との対話により、望む場面を 瞬時に取り出して見られるまでなった。

同じ頃カメラ一体型ビテオの出現て、これ まてプロの仕事てあった映像つくりは、一般 の人々てもやさしく造ることかてきるように なった。

今日ては目的にあった端末を選ふことによ って、映像の組み换えや編集が自由てきるよ うな状況にある。これは私たちが自由に情報 を操作てきる璜境が整ったのだといえる。

以上、多彩なメデアの出現やソフトの充実、 時間的な制約からの開放、多彩な表現や参加 機能の向上は、音と画筫の高品筫化と相まっ

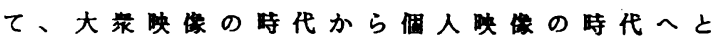
歴史的な変化を迎えている。

このことは裂品計西においても発想の転換 汃必要となった。例えば、

○技指型型ら人、生活、デサインか 经先に。 
- 身体的負担低减加精神的快感生成人。

- 物的価值少使用洒䛧、さらに意味的 価优 $。$

\section{3ハイテク化による新たな問題点}

技衙の先锐化は使用者にとって“機器の操 作がかりにくい、使いこなせない”といっ た新たな問題を生じている。特徽をいえば、

-モデルチェンジの湤化、规格の乱立、 表示の混乱、等による使い方の䧴しさ。

○サイズのバラッキ、機器接続の複雓さ、 端末の多様化等、空間に取める上ての辂 しさ。

○ブラックボックス化に伴う理解の期し さ。

このような状洨を招いている。

4 ビクターデザインの人間工学的謨題 オーティオビジュアル（以下はAVという） 装琶は主として人間の情粕に関わるソフト、 ハードシステムてある。

見る、知る、探る、心加昂等一連の $\mathrm{A} \mathrm{V}$ 行動は人間の䘽感覚を介してアクセスして いる。

一方、高度に電子化したッールは替在的に かなりの能力を借えていて、この樴能をどの ように発揮するかは使用者の技量によって異 なる。

時にはテサイイナーか予洌もしなかった使い 方を使用者が発見して、パフォーマンスして いる事さえある。

この“こだり”ともいえる行為には䡃娘 、対話、共感といったプロセスを踏まえてい ることがかる。

人と道具のあり方とは、操作を学く“わか りやすさ”と、行滖を促す“使いやすさ”の 条件とする望ましい“接点”を見出すことて あり、同時にこれはビクターのテザイン開発
における当面の人䦓工学的琵題でもある。

これを組機的に取り組むためのスローガン “接点は原点”をキーワートとして実践的に 展開した事例。

○操作をデサインする

- 行為をデサインする

ニつの主題ついて次に報告したい。

事例 1 操作をデザンする。

- 操作の結果を视見化する。

○ビデオデッキのピクトボタン操作。

-トータルコントローラーのフローをデ ザインする。

事例 2 行為をデサインする。

- 保持、安定、操作のデサイン。

-フィールトテストによってダナミッ クパランスを保䃌する。

以上 